\title{
TOWARDS POST-DIGITAL AESTHETICS
}

\author{
A B S T R A C T
}

Over the past decades, digital technology and media had firmly integrated into almost all areas of contemporary culture and society. In this context, the Internet, computers or mobile phones are no longer considered products of new media, but instead are taken for granted. With this background in mind, this paper suggests taking a post-digital perspective on today's media society. The concept of post-digital refers to an aesthetics that no longer regards digital technology as a revolutionary phenomenon, but instead as a normal aspect of people's daily life. More precisely, post-digital aesthetics deals with an environment where digital technology became such a commonplace that its existence is frequently no longer acknowledged. Based on the analysis of contemporary artworks and practices inspired by their surroundings, this paper aims to bring those phenomena into consciousness that became unnoticeable in the contemporary digital environment. For this purpose, this investigation goes beyond the formalaesthetic analysis, but instead focuses on the investigation of the receptive act. Concretely, post-digital aesthetics seeks to describe and analyze the changing modes of perception affected by the increased digitization of one's surroundings. In the context of this analysis, aesthetics is thus understood not as the goal per se, but rather as the means to enhance the understanding of contemporary digital culture. 


\section{INTRODUCTION}

Over the past decades, digital technology and media had firmly integrated into almost all areas of contemporary culture and society. In this context, they became a fully inseparable part of everyday life so that today it is almost impossible to imagine social, work, business and political life without them. For this reason, the Internet, computers, mobile phones, GPS or social media, once regarded as products of new media, are no longer considered innovations, but instead are taken for granted. Due to this growing dissemination and popularization, digital technology and media have radically changed contemporary environment, aesthetic values and sensory perceptions.

Following these developments, recent studies on aesthetics have shifted their focus from discovering of a beauty to the investigation of issues concerning appreciation of one's surroundings. In this context, several media theories have emerged with the aim to examine the impact of digital technologies on contemporary culture. ${ }^{1}$

On a related note, this paper suggests taking a post-digital perspective to critically reflect upon the consequences of dealing with digital technology. The concept of post-digital refers to an aesthetics that no longer regards digital technology as a revolutionary phenomenon, but instead as a normal aspect of people's daily life. More precisely, post-digital aesthetics deals with an environment where digital technology became such a commonplace that its existence is frequently no longer acknowledged. For this reason, this paper aims to bring into consciousness these phenomena that often remain unnoticeable in contemporary digital culture.

In doing so, post-digital aesthetics aims to investigate the receptive act instead of concentrating on formal-aesthetic analysis. In other words, postdigital aesthetics concerns not with the examination of formal qualities with the aim to discover whether something is beautiful and aesthetic pleasant. Rather, it addresses the question of how one would experience a given phenomenon. Concretely, post-digital aesthetics seeks to describe and analyze the changing modes of perception affected by the increasing digitization of one's surroundings. In this context, aesthetics is not understood as the goal per se, but rather as the means to obtain knowledge, namely that of contemporary digital culture. Hence, post-digital aesthetics addresses questions such as: How one perceives his surroundings in the context of contemporary digital technology? How one experiences virtual reality in a physical world? Is one's self-awareness and self-consciousness equal within both online and offline social lives? 
It is important to notice that post-digital aesthetics does not consider itself as a purely theoretical model. Instead, it relies on the observations taken from the analysis of contemporary artworks and practices that make use of digital technology and its effects. For this reason, post-digital aesthetics should be regarded as a sort of applied aesthetics as it observes concrete cases. Moreover, this concept examines artistic projects not as isolated objects but rather in contextual relationship to their environment and society. Therefore, postdigital aesthetics must not be limited on analysis of a concrete artistic medium but can also be extended into the investigation of one's surroundings.

\section{EXPLORING THE METAPHOR OF POST-DIGITAL}

The prefix post usually refers to events happened after a certain period of time or a sequence of activities. Following this definition, it could be argued that the concept of post-digital describes phenomena after the digital age. However, the digital age is still going on. Moreover, digital technologies are more widespread in current days than never before. At the same time, digital technologies became "invisible", and even seem to be disappearing, since we are frequently no longer aware of them. Such circumstances belong to the central theme of post-digital aesthetics. Therefore, post-digital rather means the age after the digital revolution.

The notion of Post-Digital is borrowed from American Composer Kim Cascone. In his essay The Aesthetics of Failure: 'Post-Digital' Tendencies in Contemporary Computer Music, Cascone refers to computer scientist Nicholas Negroponte, who in 1998 heralded the end of digital revolution. In this context, Cascone coins the term "post-digital" in order to describe the development of electronic music in a world where digital technologies are taken for granted. On a related note, he points to contemporary electronic musicians such as the German band Oval or the Finnish duo Pan Sonic that make use of glitch sound effects in their musical compositions. According to Cascone, this "failure" of technique, once considered a technical error or disruptive patterns, is interpreted today as aesthetically pleasant. These developments described by Cascone are meanwhile also being implemented in visuals. ${ }^{2}$

\section{LOW RESOLUTION AESTHETIC}

Usually, a strong pixelated digital image is considered low quality and unpleasant, as the appearance of the pixelation disturbs the perception of the display. Since recently, such effects of pixelation have been, however, deliberately used by many visual artists, designers and architects to create their works. This is what James Bridle - the writer and the founder of The New Aesthetic research project ${ }^{3}$ - calls "low resolution aesthetic" or "aesthetic of pixelization". ${ }^{4}$ 
The Ysios winery (Fig. 1) in Spain designed by the Spanish architect Santiago Calatrava in 2000 appears at first glance as a pixelated image. However, this is neither a computer graphic nor any other computer-generated effect. This is a real building in real life. The winery was built without using any computer animations. Indeed, the curved structure of the roof which provides the optical illusion of the pixelation is constructed by means of laminated wooden beams. ${ }^{5}$ Nevertheless, looking at the building, one certainly sees pixels.

According to James Bridle, this illusion results from the changed mode of human sense perception due to the increased use of digital technology. More precisely, Bridle argues that the way to interpret non-pixelated structures as pixelated ones, reflects the way of how the world is perceived through the "eyes" of machines. In fact, computers "see" images as an arrangement of individual pixels while human eye does not differentiate such details. On a related note, Bridle states that technology influences the way people experience the world in terms of computation. This development provides one with the possibility to discover new expressions of beautifulness. That is, the effect of strong pixelation such as seen, for example, on the building of the Ysios winery, once regarded as a technical error, is perceived as beautiful today. ${ }^{6}$

Wooden sculptures of American artist Shawn Smith also appear as lowresolution images (Fig. 2). ${ }^{7}$ In his works, Smith investigates how nature is perceived through technology. In this context, the artist points to the processes in contemporary digital environment, observing that today television and computer screen are capable of generating very realistic representation of the real world so that one indeed believes he is seeing tangible images. In the 1970s, media theorist Jean Baudrillard already developed a theory according to which industrial society endeavors to "simulate" reality through media technology such as television or computer. ${ }^{8}$ Similarly, Smith critically reflects upon these developments through his art.

In doing so, Shawn Smith creates sculptures of animals that appear as pixelated forms. However, these workpieces are wooden figures. The artist produces a pixelated effect cutting plywood sculptures into small pixel-like cubes and square dowels, and painting each of them in different colors with ink or acrylic. When looking at these sculptures, one believes to see pixelated images. On the other hand, digital images composed of individual pixels are perceived as real, tangible objects. In this context, Smiths manifests the lack of distinction between the real and the virtual in contemporary culture.

Similarly to the above discussed artists, Zaha Hadid - one of the most prominent contemporary architects - also involves effects previously considered technical 


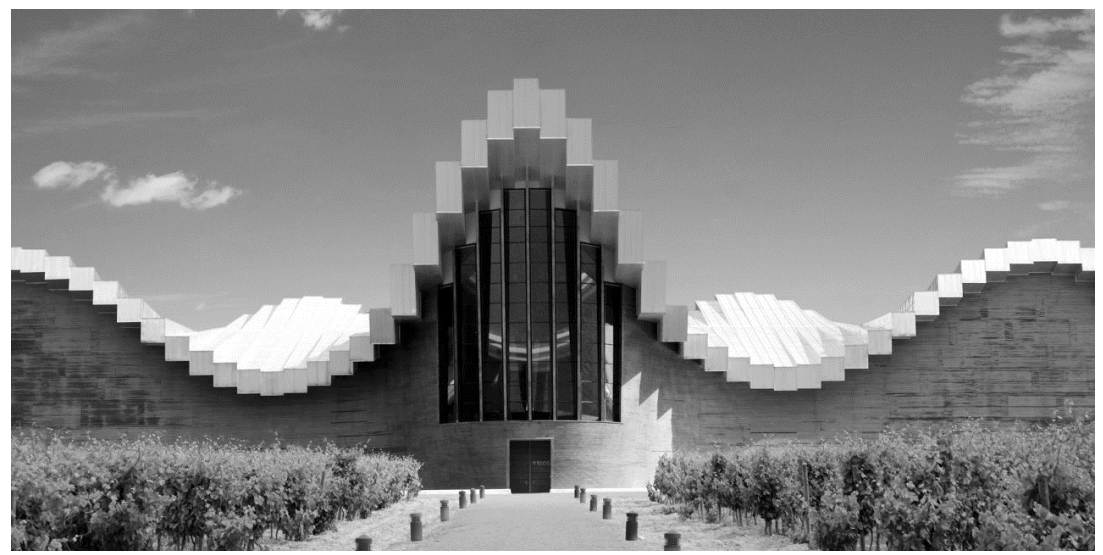

Figure 1. Santiago Calatrava, The Ysios Winery, Laguardia, Spain, 1998-2001 (source: http://buildipedia. com/aec-pros/featured-architecture/santiago-calatravas-ysios-bodegas (accessed: 10. 04. 2015)).

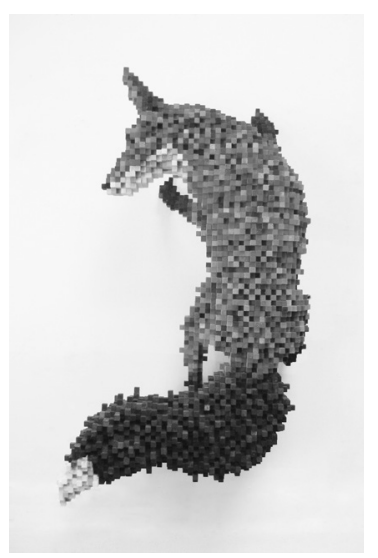

Figure 2. Shawn Smith, Spurious Skulk, balsa wood, bass wood, ink, acryl paint, 2012 (source: http:// www.shawnsmithart.com/ (accessed: 08.04.2015)).

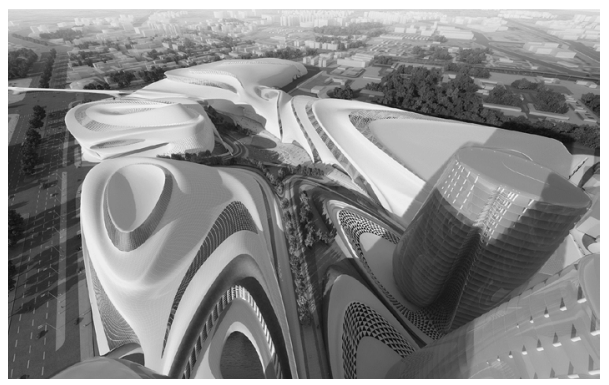

Figure 3. Soehne \& Partners, project the Code Unique Hotel in Dubai, 2008 (source: http://www.soehnepartner. com (accessed: 02. 04. 2015)).

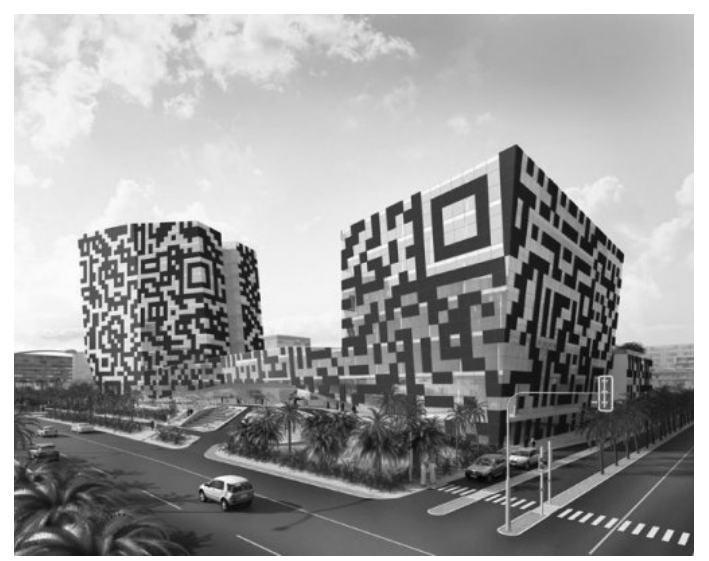

Figure 4. Zaha Hadid, proposal for an "exhibition and conference city" for Cairo, 2009 (source: http://www.archicentral.com/tag/cairo/ (accessed: 10. 04. 2015)).
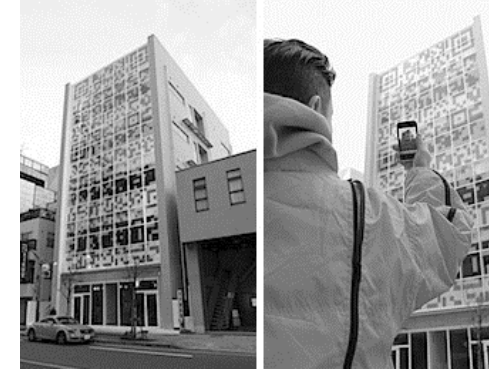

Figure 5. Terada Design Architects, N Building, Tokyo, 2009 (source: www. teradadesign.com (accessed:03. 04. 2015)). 
errors in her architectural works. ${ }^{9}$ In this context, her buildings evoke at first glance an impression of Photoshop distortion or crooked camera views. Hadid's architectural project for Cairo Expo City (Fig. 3) is an example of how the architect uses the effect of distortion as a creative method. This building complex contains several blocks connected with each other. The construction can be observed from multiple viewpoints simultaneously. Due to this multiple perspective projection, the whole building structure appears as transformed into titled and distorted forms. Hadid developes her architecture based on the visual language of digital design tools, reflecting thus machine's visual language.

\section{INTERDIMENSIONAL EXPERIENCE}

The virtual reality and physical world are usually considered two different universes. Nonetheless, the digital humanist Steven E. Jones points out that in recent years, the "digitization" of environment has provided the possibility of interdimensional experience. More specifically, according to Jones, contemporary networked environment has enabled one to experience reality as linking physical and digital dimensions. ${ }^{10}$

A QR Code (Quick Response Code) is an example of how virtual and physical dimensions can be experienced simultaneously. This is a kind of onedimensional barcode that exists in the form of an arrangement of black pixellike small squares unevenly distributed within a grid on a white background. Additionally, three distinctive squares are placed in the corners of the QR code. QR codes are usually printed on some surface such as paper or glass. This means that a QR code is a part of its material bearer, and as such it is tangible. At the same time, QR codes provide the possibility of an immediate connection with the Internet, i.e. with the virtual space. On a related note, $Q R$ codes can be considered a bridge that link the physical and the digital world. In other words, this electronic code represents physical and virtual dimensions simultaneously.

QR codes have inspired designers, artists and architects to make use of this medium. On a related note, Austrian architects Soehne \& Partners involved visual and digital media qualities of QR codes to bring their architectural ideas to life. In this context, architects developed in 2008 an project designed for a hotel complex the Code Unique Hotel in Dubai (Fig. 4). The objective of this project is to create an architectural work with a futuristic QR code design. If constructed, the exterior surface of the hotel building would be completely covered in QR codes. Additionally, the overall rectangular form of the building intended to be designed by taking into account the block-like shape of this medium. This project is planned for the film production industry Dubai Studio City, which can be considered an equivalent of Hollywood. On a related note, 
Dubai Studio City can be regarded as a place for creation of fictional stories and illusions. Accordingly, the architects of the Code Unique Hotel seek to create an atmosphere of the total illusion. In this context, the aim is to create a building that will provide an impression of being a gateway towards other realities, like QR codes. ${ }^{11}$

The architectural project $N$ Building designed by Terada Design architects (Terada Naoki, Hirate Kenichi) in 2009 also shows QR codes attached to its facade (Fig. 5). This is a commercial building. Scanning QR codes of the facade, it is possible to obtain any shop information, make online orders or download discount coupons. Nevertheless, the QR code here goes beyond the pure functional use, having also symbolical significance. The idea to use symbols on building facades suggests associations with Gothic cathedrals such as Reims or Chartres, the portals of which are considered symbolical representation of the Heavenly Jerusalem. In other words, Gothic cathedrals represent physical appearance and the transcendent and intangible reality simultaneously. Similarly, $N$ Building enables one to experience the virtual space accessible through mobile device and the physical world in the form of commercial building at the same time. ${ }^{12}$

\section{CHANGING SELF-PERCEPTION AND SELF-OBSERVATION}

Social media platforms such as Facebook, Twitter or Instagram as well as video games evoke new forms of self-perception. When creating a video game avatar or a social media profile, one creates his second "identity" that can be performed exclusively within an online space. This fact transforms existing perception of identity since one can exist as online and real-life persona at the same time.

The project LaTurbo Avedon makes explicit reference to this phenomenon. LaTurbo Avedon is a contemporary female web-based artist who is a real and virtual person simultaneously. ${ }^{13}$ Within this project, the real identity of the artist remains however unknown. The audience knows her exclusively as a female avatar named LaTurbo Avedon. It remains hidden whether there is any reference between artist's online and real lives. Using this female avatar as a new identity, LaTurbo Avedon promotes her digital works in virtual space. In this context, she creates three-dimensional virtual environments or other 3D sculptural appearances which are accessible only through the web. This means that the artist's existence as well as her creative outputs depends solely on the virtual world: neither LaTurbo Avedon nor her work could ever exist outside of computers. 
The growing use of social networks arise another question, namely that of privacy. Is it possible today to escape intensive cyber-control? In this context Hito Steyerl's work HOW NOT TO BE SEEN: A Fucking Didactic Educational .Mov File provides a parodical instruction on how to remain invisible in an age of digital surveillance, of the total visibility. In 2013, this video installation was exhibited at the Venice Biennale. In this work, the artist suggests that one can disappear for example by going offline. Other strategies to avoid being seen proposed in this video are ironic: one can choose, for example, to paint, to camouflage oneself or to become smaller than a pixel. A background computerized voice reads out: "Today the most important things want to remain invisible. Love is invisible. War is invisible. Capital is invisible." Several faceless figures appear on camera to demonstrate these suggested strategies. The video ends with the disappearance of the film crew. At their place, digital ghosts suddenly appear. On a related note, Steyerl argues that those who desire to disappear in the digital age appear as technological ghosts in the internet world. ${ }^{14}$

Nonetheless, in Hito Speyerl's video film, it is most probably not a question of how not to be seen, it is rather a question of how one can be able to clearly see and to critically reflect upon the contemporary digital transformations.

\section{FINAL CONSIDERATIONS}

In contemporary culture, the way in which one perceives his surroundings is primarily shaped by media and digital technologies. In this context, aesthetics plays a crucial role. However, this does not imply such aesthetics that is interested in the questions of beautifulness. Rather, it refers to aesthetics that focuses on the perceptive act, since such perspective can contribute to the understanding of perception process within increased digitization of contemporary environment.

With this background in mind, post-digital aesthetics suggested in this paper should provide sources and observations for critical reflection upon the consequences of dealing with digital technology. In this context, the proposed conception should describe implications in relation to an environment where digital technology and media are such a commonplace that their existence is frequently no longer acknowledged - development that in contemporary culture seems to be fully taken for granted. On a related note, post-digital aesthetics should make invisible visible. Concretely, it should develop an awareness of changing perceptions of reality within a world where the real and the virtual dimension flow in each other, where one frequently does not know whether something is analogue or digital. Within this paper, the concept of post-digital aesthetics was examined relying on examples from artistic projects that critically reflect upon digitization of contemporary culture. For this reason, observation obtained from this analysis can also be applied to the appreciation of contemporary culture in general. 
See, for example, Lev Manovich, Software Takes Command (New York: Bloomsbury Academics, 2013); Lev Manovich, Software Culture, trans. Matteo Tarantino (Milan: Edizioni Olivares, 2010). Kim Cascone, "Composition and Performance - The Aesthetics of Failure: 'Post-Digital' Tendencies in Contemporary Computer Music,” Computer Music Journal 24 (2000):12-18. The New Aesthetic is an ongoing research project by James Bridle that circulates around the Tumbrl blog (http://new-aesthetic.tumblr.com/) documenting examples of products and artworks that reflect on the increasing use of technology. 2011, accessed May 4, 2015, http://www.webdirections.org/resources/james-bridle-waving-atthe-machines/. com/projects/bodegas-ysios-winery-guardia.html.

James Bridle, "Waving at the Machines," the Australian Web Industry Conference, October 11-14, 2011, accessed May 4, 2015, http://www.webdirections.org/resources/james-bridle-waving-atthe-machines/. Shawn Smith's official website, accessed May 15, 2015, http://shawnsmithart.com/images.htm. Jean Baudrillard, "Requiem für die Medien," in Kool Killer oder Aufstand der Zeichen, ed. Jean Baudrillard (Berlin: Merve Verlag, 1970), 83-118.

See, Zaha Hadid's official website, accessed May 15, 2015, http://www.zaha-hadid.com/; Zaha Hadid, Zaha Hadid: Complete Works 1979-2013 (Cologne: Taschen, 2013); Sonia Ricon Baldessarini, Wie Frauen bauen: Architektinnen von Julia Morgan bis Zaha Hadid (Berlin et al.: Aviva, 2001), 161-178.

Steven E. Jones, The Emergence of Digital Humanities, (New York et al.: Routlege, 2014), 39-48. soehnepartner.com/projekte/studio-city-hotel.

12 See, Vimeo Video, accessed May 15, 2015, https://vimeo.com/8468513. 
Baudrillard, Jean "Requiem für die Medien.” In Kool Killer oder Aufstand der Zeichen, edited by Jean Baudrillard, 83-118. Translated by Hans-Joachim Metzger. Berlin: Merve Verlag, 1970. Cascone, Kim, "Composition and Performance - The Aesthetics of Failure: 'Post-Digital' Tendencies in Contemporary Computer Music.” Computer Music Journal 24 (2000):12-18. Hadid, Zaha. Zaha Hadid: Complete Works 1979-2013. Cologne: Taschen, 2013.

Jones, Steven E. The Emergence of Digital Humanities. New York et.al.: Routlege, 2014.

Manovich, Lev. Software Culture. Translated by Matteo Tarantino. Milan: Edizioni Olivares, 2010.

Manovich, Lev. Software Takes Command. New York: Bloomsbury Academics, 2013.

Ricon Baldessarini, Sonia. Wie Frauen bauen: Architektinnen von Julia Morgan bis Zaha Hadid. Berlin et al.: Aviva, 2001 


\section{'UČENJE OD DETROITA?' \\ OD MATERIJALIZOVANIH SNOVA DO GORKOG BUĐENJA ESTETIKE OKO DOTRAJALIH TRŽNIH CENTARA \\ Zoltán Somhegyi}

Tržni centri su bili i još uvek su naročito popularni jer su prvi izgrađeni 1950-ih. Zanimljivo, i njihovi česti posetioci i njihovi najveći kritičari ih vide kao materijalizaciju sna potrošačkog društva. Oni se tako često smatraju gotovo 'hramovima' konzumerizma, gde aktivnost 'kupovine' zamenjuje druge, tradicionalnije oblike društveno-kulturnog angažmana. U poslednjih nekoliko godina možemo iskusiti sve veće interesovanje za dokumentacijom propalih centara sa melanholično-nostalgičnog stanovišta u sanjive vizije koje u nekim slučajevima čine slike sličnim klasičnom predstavljanju antičkih ruševina. Da li je to samo slučajnost, ili postoji paralela između uvažavanja ostataka hramova antike i ruševina hramova konzumerizma? U slučaju da da, šta onda možemo da naučimo od pokušaja estetizacije ovog propadanja? Ono što ove serije umetničkih dela mogu otkriti o našem sadašnjem stanju i pristupu prostoru, zabavi, konzumaciji i životu? Ja dovodim u svom ispitivanju neka razmatranja o Detroitu, ne (samo) o samom gradu, koji je postao referentna tačka, a ponekad čak i "igralište" za analizu savremenog propadanja, već i Detroitu kao fenomenu ili simbolu, kao i neka razmatranja na osnovu ponovnog čitanja prekretnice knjige Venturija, Brauna i Izenura.

KLJUČNE REČI: RUŠENJE I NJEGOVO PREDSTAVLJANJE, KLASIČNE I “SAVREMENE” RUŠEVINE, ESTETIKA PROPADANJA, TRŽNI CENTRI, IZGRAĐENO NASLEĐE I OČUVANJE

\section{PREMA POST-DIGITALNOJ ESTETICI}

\section{Anna Daudrich}

Tokom proteklih decenija, digitalna tehnologija i mediji su se čvrsto integrisali u skoro svim oblastima savremene kulture i društva. U tom kontekstu, internet, kompjuteri i mobilni telefoni se više ne smatraju proizvodima novih medija, već se uzimaju zdravo za gotovo. Sa ovom pozadinom na umu, ovaj rad predlaže uzimanje post-digitalnog pogleda na današnje medijsko društvo. Koncept 'post-digitalno' odnosi se na estetiku koja više ne posmatra digitalnu tehnologiju kao revolucionarnu pojavu, već kao normalan aspekt svakodnevnog života ljudi. Tačnije, postdigitalna estetika se bavi okruženjem gde je digitalna tehnologija postala tako uobičajena, da se njeno postojanje često ne priznaje. Na osnovu analize savremenih umetničkih dela i prakse inspirisane svoje okoline, ovaj rad ima za cilj da dovede te fenomene u svest koja je postala neprimetna u savremenom digitalnom okruženju. U tu svrhu, ova istraga prevazilazi formalnoestetske analize, već se fokusira na istragu o receptivnom aktu. Konkretno, post- digitalna estetika nastoji da opiše i analizira promenljive oblike percepcije pod uticajem povećane digitalizacije okoline. U kontekstu ove analize, estetika se stoga razume ne kao cilj sama po sebi već kao sredstvo da se poboljša razumevanje savremene digitalne kulture.

KLJUČNE REČI: POST-DIGITAL, DIGITALNA TEHNOLOGIJA, ESTETIKA, PROMENJENO ISKUSTVO PERCEPCIJE

KONJUNKCIJA UMETNOSTI I ŽIVOTA: ONTOLOGIJA MESTA

\section{Bojana Matejić}

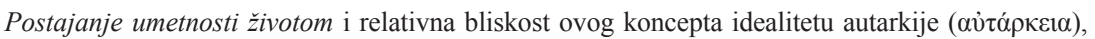
implicira maksimu koja koincidira sa emancipatorskim obećanjem umetnosti. Autori neomarksističkog kruga su pripisali ovu maksimu, po svemu sudeći, Marksovim ranim radovima, naročito određenom setu teza iz njegovih Ekonomsko-filozofskih rukopisa iz 1844. i elaborirali je, dalje, na ovim osnovama. Ova maksima je bila primenjena u mnogim avangardnim praksama do danas: Brehtovo političko pozorište, Deborov situacionizam, specifična mesta (site-specific), flukus, socijalna skulptura Jozefa Bojsa, itd. Zajednički imenitelj svih ovih avangardnih praksi može biti označen imperativom afirmacije njihove upotrebne vrednosti - njihove realizacije na mestu vlastite proizvodnje, spram apstraktnosti njihovog postavljanja u svet. Mesto ove proizvodnje jeste mesto same proizvodnje društvenosti. Shodno tome, cilj ovog rada jeste preispitivanje maksime o postajanju umetnosti životom, u svetlu Badiouove ontologije mesta i na primeru modaliteta radova specifičnih mesta u uslovima savremenosti. 